\title{
Royal jelly-derived proteins enhance proliferation and migration of human epidermal keratinocytes in an in vitro scratch wound model
}

Yan Lin ${ }^{1 \dagger}$, Qiqi Shao ${ }^{1+}$, Meng Zhang ${ }^{1}$, Chenyue Lu' ${ }^{1}$, Joy Fleming ${ }^{2}$ and Songkun Su ${ }^{1 *}$

\begin{abstract}
Background: Skin injury is inevitable in daily life. In recent years, with the increasing morbidity of diseases such as diabetes and metabolic disorders, chronic wounds have become a considerable challenge in clinical practice. Royal jelly, reported to have multifarious biological and physiological properties, has been used as a remedy for a variety of wounds since ancient times. However, the active components and mechanisms underlying the wound-healing properties of royal jelly are still largely unknown.
\end{abstract}

Methods: Water-soluble proteins of royal jelly were fractionated and investigated for the proliferative and migratory effects on human epidermal keratinocytes ( $\mathrm{HaCaT}$ ) in an in vitro wound healing model. The proteins present in bioactive fractions were characterised and quantified using Label-free protein quantification method. The potential functions of these proteins in biological systems were further analysed using bioinformatic tools.

Results: A protein fraction, mainly containing major royal jelly proteins 2 (MRJP2), MRJP3 and MRJP7, stimulated proliferative and migratory activities in $\mathrm{HaCaT}$ cells without visible cytotoxicity. It exerted the greatest effects on the growth of $\mathrm{HaCaT}$ cells in the first $48 \mathrm{~h}$. Furthermore, when treated with this protein fraction, the closure rates of the in vitro scratch wound were significantly increased. Functional analysis indicated that MRJP2, MRJP3 and MRJP7 were associated with carbohydrate transport and metabolism.

Conclusions: We fractionated the water-soluble proteins of royal jelly and identified one fraction (Fraction 2) that induced both proliferative and migratory effects on a human epidermal keratinocyte cell line. Major royal jelly proteins (MRJP2, MRJP3 and/or MRJP7) were speculated to possess potential wound-healing bioactivity. This is the first report that royal jelly may improve wound closure via MRJP-induced cellular proliferation and migration. These proteins may be valuable lead compounds for the development of novel wound healing medications. Our findings would facilitate better understanding of the wound repair mechanisms of royal jelly.

Keywords: Royal jelly, Human epidermal keratinocytes, Major royal jelly proteins, Wound healing

\footnotetext{
* Correspondence: susongkun@zju.edu.cn

${ }^{\dagger}$ Yan Lin and Qiqi Shao contributed equally to this work.

${ }^{1}$ College of Bee Science, Fujian Agriculture and Forestry University, Fuzhou

350002, China

Full list of author information is available at the end of the article
}

(c) The Author(s). 2019 Open Access This article is distributed under the terms of the Creative Commons Attribution 4.0 International License (http://creativecommons.org/licenses/by/4.0/), which permits unrestricted use, distribution, and reproduction in any medium, provided you give appropriate credit to the original author(s) and the source, provide a link to the Creative Commons license, and indicate if changes were made. The Creative Commons Public Domain Dedication waiver (http://creativecommons.org/publicdomain/zero/1.0/) applies to the data made available in this article, unless otherwise stated. 


\section{Background}

Royal jelly, food given exclusively to larvae and queen bees, is synthesised and secreted by the glands located in the hypopharynx and mandible of nurse honeybees. It is composed of $60-70 \%$ water, $11-23 \%$ carbohydrate, 9$18 \%$ protein, $4-8 \%$ lipid and $0.8-3 \%$ other compounds such as vitamins, salts, amino acids and minerals [1-4]. To date, major royal jelly proteins (MRJPs) consisting of nine members (MRJP1-9) with molecular weight from 49 to $87 \mathrm{kDa}$ have been identified in royal jelly and taken up $83-90 \%$ of its total protein content [5].

Many studies have reported that royal jelly possesses a plethora of biological activities, including antimicrobial [6-9], anti-inflammatory [10], anti-tumour [11], antioxidant [12], immunomodulatory [13] and growthpromoting [14] effects. What is more, it has been documented to be used in folk medicine for the facilitation of wound healing since ancientry [15]. Although some studies have indicated that topical application of royal jelly can shorten the period of infected or uninfected wound healing in animal models and even diabetic foot ulcers [16-18], the substances and precise mechanisms associated with wound healing are still poorly investigated. Previous studies merely reported that royal jelly components, especially 10-hydroxy-2-decenoic acid (10HDA) and defensin-1, might accelerate wound healing through anti-inflammation, promoting synthesis of growth factors, or migration of skin fibroblasts or keratinocytes [15, 19-22]; MRJPs could induce proliferation of several human cell lines [23].

Wound healing generally occurs naturally without any external interference. Nevertheless, if handled improperly or not dealt with promptly, wounds easily become infected. Clinical treatment of wounds may involve cleaning, disinfection, suturing, antibiotic treatment and dermatoplasty. To date, there is no effective medicine or therapeutic method for the treatment of intractable wounds such as gravely infected wounds or diabetic foot ulcers, resulting in significant suffering to patients, seriously affecting their quality of life, and imposing a severe financial burden on both families and society. It is therefore of significant clinical importance to discover pharmacologically-active substances that create conditions conducive to the process of wound healing and to clarify the precise molecular mechanisms related to their actions.

Here, we explored the wound-repairing activity of royal jelly proteins using keratinocytes which are a type of cells prominently spread in epidermis and are critical in wound healing process, particularly in epithelialization. A water-soluble protein fraction mainly consisting of MRJP2, MRJP3 and MRJP7 was found to induce proliferative and migratory effects in human epidermal keratinocytes ( $\mathrm{HaCaT})$ without obvious cytotoxicity, implying the potential of MRJPs in the healing of cutaneous wounds. This is the first report that royal jelly may improve wound closure via MRJP-induced cellular proliferation and migration. Our findings facilitate greater understanding of the wound-healing actions of royal jelly and suggest that MRJPs may have potential applications in the treatment of wound healing disorders and diabetic foot ulcers.

\section{Methods \\ Cell culture}

A human epidermal keratinocyte cell line ( $\mathrm{HaCaT}$ cells, DSMZ No. 771) was purchased from DSMZ, Germany, and was routinely cultured in Dulbecco's Modified Eagle's Medium (DMEM) (Hyclone, USA) containing $10 \%$ foetal bovine serum (FBS) (Hyclone, USA) and 1\% penicillin-streptomycin solution (TransGen Biotech, China) at $37^{\circ} \mathrm{C}$ in an incubator with humidified atmosphere and $5 \% \mathrm{CO}_{2}$.

\section{Royal jelly sample}

Fresh royal jelly produced by Fengqiang No. 1 (Apis mellifera ligustica) offspring colonies was harvested from a local apiary in Jiangsu Province, P.R. China, and was deposited in a freezer $\left(-20^{\circ} \mathrm{C}\right)$ prior to use. No permission was necessary for the collection of royal jelly.

\section{Fractionation of royal jelly}

Royal jelly ( $10 \mathrm{~g}$ ) was homogenized in $40 \mathrm{ml}$ of phosphate buffered saline (PBS). Extraction of water-soluble proteins: the royal jelly homogenate was vortexed vigorously at intervals then left to stand on ice over a period of $30 \mathrm{~min}$. The supernatant obtained following centrifugation at $10,000 \times \mathrm{g}$ for $40 \mathrm{~min}$ at $4{ }^{\circ} \mathrm{C}$ was dialysed against $2 \mathrm{~L}$ of $\mathrm{PBS}$ for 3 days at $4{ }^{\circ} \mathrm{C}$. The dialysate was further centrifuged as previously, which was followed by lyophilising the final supernatant in a freeze dryer (Thermo Fisher Scientific, USA) and then storing at $80^{\circ} \mathrm{C}$ before use. The concentration of water-soluble proteins was determined using BCA protein assays [24]. Approximately $50 \mathrm{mg}$ of lyophilised protein was reconstituted in $10 \mathrm{ml}$ of deionised water, $500 \mu \mathrm{l}$ of which was subjected to an ÄKTA ${ }^{\text {Tw}}$ pure system (GE Healthcare, USA) fitted with a Tricorn ${ }^{\text {tw }}$ Superdex 75 Increase 10/ $300 \mathrm{GL}$ high performance column $(10 \times 300 \mathrm{~mm}, 9 \mu \mathrm{m}$, GE Healthcare, USA). Deionised water $(0.7 \mathrm{ml} / \mathrm{min})$ and $\lambda 280 \mathrm{~nm}$ wavelength were applied for elution and effluent absorbance detection, respectively. Fractions derived from discrete absorbance peaks were collected and lyophilised.

\section{Electrophoretic analysis of fractions}

Fractionated proteins were analysed electrophoretically using 12\% SDS-PAGE gels in which Blue Plus Protein 
Marker (Transgen, China) was included as a molecular weight protein standard. Electrophoresis was followed by staining the gels with Coomassie Brilliant Blue R-250 to preliminarily analyse the protein composition in each fraction.

\section{MTT cell viability assay}

$\mathrm{HaCaT}$ cells $(100 \mu \mathrm{l})$ suspended in DMEM at a density of $5 \times 10^{4}$ cells $/ \mathrm{ml}$ were seeded onto each well of 96-well plates and incubated at $37^{\circ} \mathrm{C}$ for $24 \mathrm{~h}$ in a $\mathrm{CO}_{2}$ incubator. The medium was replaced with serum-free DMEM for cell starvation for $12 \mathrm{~h}$, and the cells were subsequently treated with royal jelly fractions, bovine serum albumin (BSA, $3.2 \mu \mathrm{g} / \mathrm{ml}$ ) or serum-free DMEM (control) for 24,48 or $72 \mathrm{~h}$. Then, they were incubated for a further $4 \mathrm{~h}$ after addition of $10 \mu \mathrm{l}$ of $5 \mathrm{mg} / \mathrm{ml} \mathrm{3-(4,5-Di-}$ methylthiazol-2-yl)-2,5-diphenyltetrazolium bromide (MTT) solution (Beyotime, China). The generated formazan crystals were dissolved in $100 \mu \mathrm{l}$ of DMSO following removal of the supernatant. Cell viability was determined by the absorbance at $492 \mathrm{~nm}$ in an Infinite F50 plate reader (Tecan, Austria), and expressed as \%

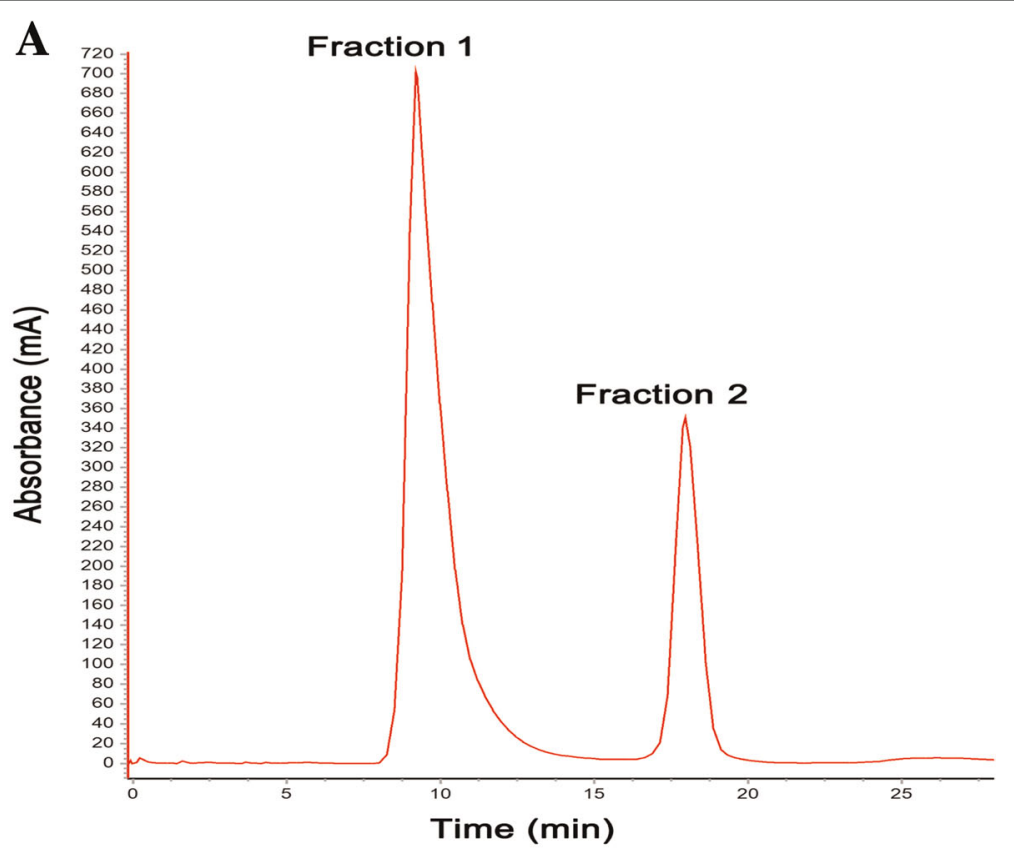

B

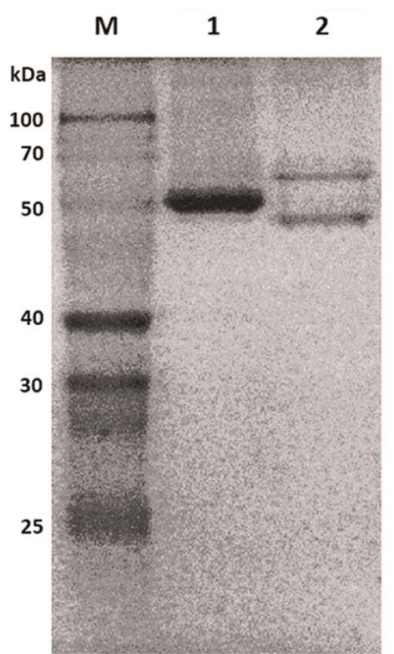

Fig. 1 Isolation of proteins from royal jelly. a Fractionation of royal jelly water-soluble proteins using an ÄKTA ${ }^{\text {TM}}$ pure system. The elution positions/ retention times of Fractions 1 and 2 are indicated. $\mathbf{b}$ SDS-PAGE analysis of the protein content of the collected fractions. Lane 1 and lane 2 are the proteins in Fractions 1 and 2, respectively. M represents molecular weight protein standard 
cell viability $=$ absorbance of protein treated cells/absorbance of serum-free medium treated cells $\times 100 \%$.

\section{Scratch-wound assays}

Cell migration effects were evaluated using scratch-wound assays. Culture-Inserts (ibidi, Germany) were placed in each well of 24-well plates. A volume of $70 \mu \mathrm{l}$ of $\mathrm{HaCaT}$ cells $\left(5 \times 10^{5}\right.$ cells $\left./ \mathrm{ml}\right)$ was seeded in each cell of the CultureInsert and cells were cultured as monolayers to confluency for about $18 \mathrm{~h}$ in a $\mathrm{CO}_{2}$ incubator. Culture-Inserts were removed carefully to form an approximately 500- $\mu$ m-wide cell free gap, and cells were washed twice to remove nonadherent cells. To observe the effects of royal jelly protein fractions on keratinocyte migration, cells were treated with a series of the protein fractions at different concentrations prepared in serum-free DMEM or with serum-free medium (control). The wounded cell monolayer was observed under a phase-contrast microscope (Olympus, Tokyo, Japan) and images (three per well, captured randomly) were taken at 0 and $24 \mathrm{~h}$ following the infliction of wounds which was a cell free nick created by Culture-Inserts [25]. Closure of wounds was measured using Image J software (National
Institutes of Health, Bethesda, MD, USA). Wound closure rates were expressed as percentages of the wound area closed at $24 \mathrm{~h}$ relative to the initial area of the cell-free region at $0 \mathrm{~h}$. Three replications of each treatment were included in each experiment and all experiments were replicated independently three times.

\section{Identification and quantitative analysis of fractions possessing bioactivity}

Label-free protein quantification was performed using an Easy nanoLC 1200 chromatograph (Thermo Scientific, USA) and Q Exactive HF-X mass spectrometer (Thermo Scientific, USA) to identify and quantify the proteins in the fraction displaying bioactivity. Briefly, samples were loaded onto a pre-column (Acclaim $^{\text {TM }}$ PepMap $^{\mathrm{Tm}} 100 \mathrm{C} 18,2 \mathrm{~cm} \times 100 \mu \mathrm{m}, 5 \mu \mathrm{m}$, Dionex, USA) and an analytical column (Reprosil-AQ Pur C18, $15 \mathrm{~cm} \times$ $150 \mu \mathrm{m}, 1.9-\mu \mathrm{m}$ particle, Dr. Maisch, Germany) that was eluted with a linear gradient formed from 95\% Solvent A (formic acid/water, 0.1/99.9, v/v) $+5 \%$ Solvent B (formic acid/acetonitrile (ACN)/water, $0.1 / 80 / 19.9, \mathrm{v} / \mathrm{v} / \mathrm{v})$ to $10 \%$ Solvent $A+90 \%$ Solvent B over $60 \mathrm{~min}$. In the Easy-

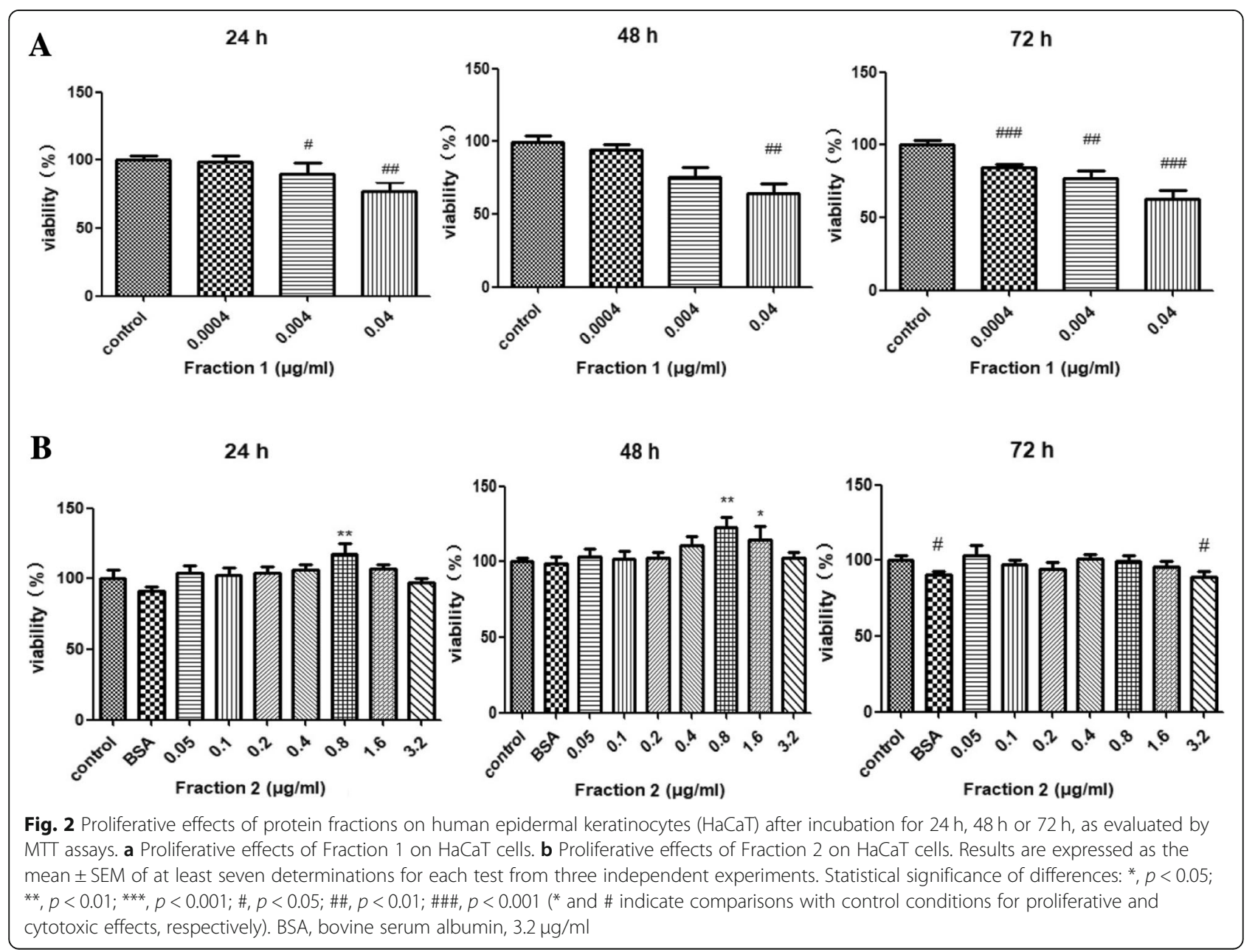


spray ion source, the spray voltage and the heated capillary temperature were set to $3.2 \mathrm{kV}$ and $320^{\circ} \mathrm{C}$, respectively. Proteins were identified by searching the C101SC18010979-uniprot-Apis-mellifera protein database. Percentages of proteins were calculated by the area of absorption peak of each protein relative to that of total protein.

\section{Functional analysis of the proteins identified in bioactive fractions}

The structural features and potential functions of the proteins present in the bioactive fractions were analysed and annotated by InterPro [26], Cluster of Orthologous Groups (COG) [27], Gene Ontology (GO) [28], and Kyoto Encyclopedia of Genes and Genomes (KEGG) [29] databases in conjunction with BLAST search [30].

\section{Statistical analysis}

GraphPad Prism 5.0 software (GraphPad Software Inc., CA, USA) was employed for statistical analysis, in which one-way ANOVA was used for comparisons of variance. Results with $p$-values less than 0.05 were regarded to be statistically significant. Values were expressed as means \pm SEM.

\section{Results}

Isolation and electrophoretic analysis of proteins from royal jelly

Isolation of royal jelly proteins by size exclusion chromatography using an ÄKTA ${ }^{\text {tw }}$ pure system (GE Healthcare, USA) revealed that two major protein peaks (Fraction 1 and Fraction 2) were eluted at retention times of about 9.5 and $18 \mathrm{~min}$, respectively (Fig. 1a). SDS-PAGE analysis indicated that Fraction 1 was composed of a single protein band with molecular weight of around 55 $\mathrm{kDa}$, and Fraction 2 of two protein bands with molecular weights of $50-60 \mathrm{kDa}$ (Fig. 1b).

\section{Proliferative effect of protein fractions on human epidermal keratinocytes}

The proliferative effect of the royal jelly proteins in these fractions on $\mathrm{HaCaT}$ cells was examined. Regardless of the duration of treatment, Fraction 1 was found to be devoid of growth-promoting activity on the cell line at concentrations up to $40 \mathrm{ng} / \mathrm{ml}$ and demonstrated severe cytotoxicity at high concentrations (Fig. 2a), which was similar to the effects of MRJP1 (data not shown). By contrast, Fraction 2 exhibited the efficacy of facilitating the proliferation of $\mathrm{HaCaT}$ cells at 0.8 and $1.6 \mu \mathrm{g} / \mathrm{ml}$ without causing obvious toxicity at any concentration.

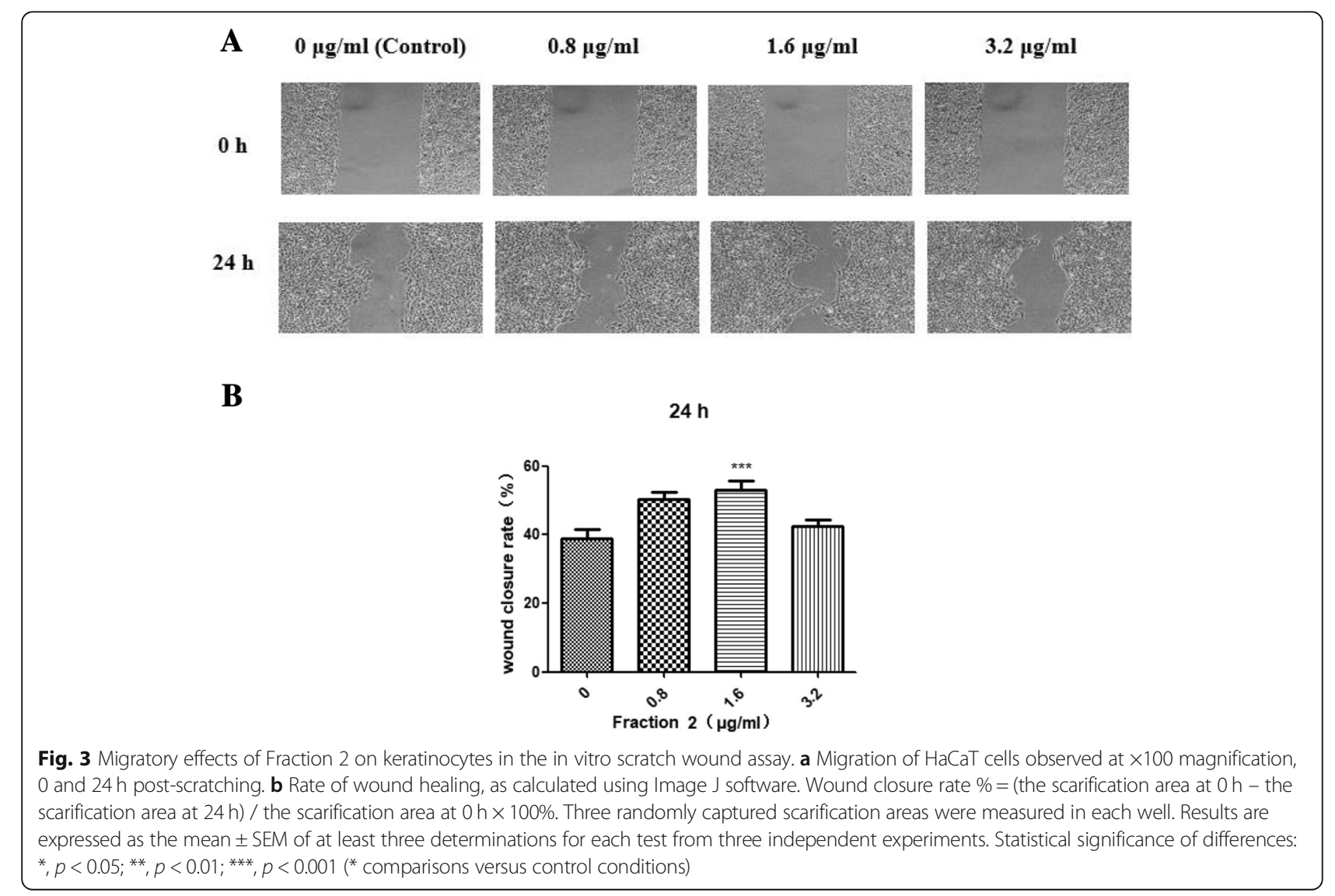


Table 1 Identification and quantification of proteins in Fraction 2

\begin{tabular}{|c|c|c|c|}
\hline Accession & Description & Abundances & Percentages \\
\hline A0A1Q1N6G0 & Major royal jelly protein $2 \mathrm{OS}=$ Apis mellifera carnica GN $=$ MRJP2 $\mathrm{PE}=4 \mathrm{SV}=1$ & 12095077555 & $56.443 \%$ \\
\hline D3Y5T0 & Major royal jelly protein OS $=$ Apis mellifera $G N=$ MRJP3 PE $=2 \mathrm{SV}=1$ & 6424005583 & $29.979 \%$ \\
\hline O77061 & Major royal jelly protein $2 \mathrm{OS}=$ Apis mellifera $\mathrm{GN}=\mathrm{MRJP2} \mathrm{PE}=1 \mathrm{SV}=1$ & 788699090.3 & $3.681 \%$ \\
\hline A0A087ZRA1 & Uncharacterized protein OS = Apis mellifera PE $=3 \mathrm{SV}=1$ & 540461377.8 & $2.522 \%$ \\
\hline Q6IMJ9 & Major royal jelly protein $7 \mathrm{OS}=$ Apis mellifera $\mathrm{GN}=\mathrm{MRJP7} \mathrm{PE}=2 \mathrm{SV}=1$ & 345406314 & $1.612 \%$ \\
\hline 018330 & Major royal jelly protein $1 \mathrm{OS}=$ Apis mellifera $\mathrm{GN}=\mathrm{MRJP} 1 \mathrm{PE}=1 \mathrm{SV}=1$ & 202611735 & $0.946 \%$ \\
\hline A0A087ZW88 & Uncharacterized protein OS = Apis mellifera PE $=4 \mathrm{SV}=1$ & 174868784 & $0.816 \%$ \\
\hline A0A087ZQ15 & ATP synthase subunit alpha OS $=$ Apis mellifera $G N=$ Atp5a1 PE $=3 \mathrm{SV}=1$ & 130414480 & $0.609 \%$ \\
\hline A0A087ZRE3 & Elongation factor 1-alpha OS $=$ Apis mellifera GN $=E F 1$ a-F2 PE $=3 \mathrm{SV}=1$ & 117294891.1 & $0.547 \%$ \\
\hline A0A088A436 & Tubulin alpha chain OS $=$ Apis mellifera $\mathrm{GN}=\mathrm{LOC550827} \mathrm{PE}=3 \mathrm{SV}=1$ & 113409161.6 & $0.529 \%$ \\
\hline A0A088AN20 & Uncharacterized protein OS $=$ Apis mellifera GN $=$ RpL40 PE $=4$ SV $=1$ & 65715884.16 & $0.307 \%$ \\
\hline Q4ZJX1 & Major royal jelly protein 9 OS $=$ Apis mellifera $\mathrm{GN}=\mathrm{MRJP9} P \mathrm{PE}=2 \mathrm{SV}=1$ & 58901241 & $0.275 \%$ \\
\hline A0A087ZQ27 & Uncharacterized protein $\mathrm{OS}=$ Apis mellifera $\mathrm{PE}=3 \mathrm{SV}=1$ & 44876322.19 & $0.209 \%$ \\
\hline A0A088AMB8 & ATP synthase subunit beta OS $=$ Apis mellifera $G N=$ Atp5b PE $=3 \mathrm{SV}=1$ & 30241432 & $0.141 \%$ \\
\hline A0A088AEZ4 & Tubulin alpha chain OS $=$ Apis mellifera $\mathrm{GN}=\mathrm{LOC552766} \mathrm{PE}=3 \mathrm{SV}=1$ & 24948560 & $0.116 \%$ \\
\hline A0A088A5A6 & Uncharacterized protein OS = Apis mellifera GN $=\mathrm{LOC} 409481 \mathrm{PE}=3 \mathrm{SV}=1$ & 20733956.13 & $0.097 \%$ \\
\hline W8S9B2 & Actin (Fragment) OS=Nosema ceranae PE $=3 \mathrm{SV}=1$ & 19727244.75 & $0.092 \%$ \\
\hline H9KL77 & Histone H4 OS = Apis mellifera GN $=$ LOC724757 PE $=3 \mathrm{SV}=1$ & 17945946.88 & $0.084 \%$ \\
\hline A0A087ZNX0 & Uncharacterized protein OS $=$ Apis mellifera GN $=$ Rab11 PE $=4 \mathrm{SV}=1$ & 16626939 & $0.078 \%$ \\
\hline A0A087ZSC1 & Tubulin beta chain OS $=$ Apis mellifera GN $=$ LOC410559 PE $=3$ SV $=1$ & 14751532.47 & $0.069 \%$ \\
\hline A0A088AJJ6 & Uncharacterized protein OS = Apis mellifera GN $=$ LOC411989 PE $=3 \mathrm{SV}=1$ & 14168904 & $0.066 \%$ \\
\hline A0A088AGJ8 & Uncharacterized protein OS = Apis mellifera GN $=\mathrm{LOC410620} \mathrm{PE}=3 \mathrm{SV}=1$ & 11988349 & $0.056 \%$ \\
\hline A0A088A5X7 & Uncharacterized protein OS = Apis mellifera GN $=\mathrm{LOC} 409167 \mathrm{PE}=4 \mathrm{SV}=1$ & 11909793.5 & $0.056 \%$ \\
\hline A0A088A3F4 & Uncharacterized protein OS $=$ Apis mellifera GN $=\mathrm{LOC727045} \mathrm{PE}=4 \mathrm{SV}=1$ & 11490301.06 & $0.054 \%$ \\
\hline A0A088A2A5 & Uncharacterized protein OS $=$ Apis mellifera GN $=\mathrm{LOC552272} \mathrm{PE}=3 \mathrm{SV}=1$ & 11100238 & $0.052 \%$ \\
\hline A0A087ZUL8 & Uncharacterized protein OS = Apis mellifera GN $=\operatorname{RpS15} \mathrm{PE}=3 \mathrm{SV}=1$ & 10443703 & $0.049 \%$ \\
\hline A0A087ZR05 & Uncharacterized protein OS = Apis mellifera GN $=$ Rpn11 PE $=4 \mathrm{SV}=1$ & 9778002 & $0.046 \%$ \\
\hline A0A087ZV73 & Uncharacterized protein OS $=$ Apis mellifera $G N=L O C 724873 \mathrm{PE}=4 \mathrm{SV}=1$ & 8411322 & $0.039 \%$ \\
\hline A0A087ZMS7 & Uncharacterized protein OS = Apis mellifera GN $=$ Rab39 PE $=4$ SV $=1$ & 7275442.125 & $0.034 \%$ \\
\hline A0A088A6D6 & Uncharacterized protein OS = Apis mellifera GN=Ndufs3 PE $=3 \mathrm{SV}=1$ & 6409224.875 & $0.030 \%$ \\
\hline A0A088A7D1 & Uncharacterized protein OS $=$ Apis mellifera GN $=\mathrm{LOC410306} \mathrm{PE}=3 \mathrm{SV}=1$ & 6343857.5 & $0.030 \%$ \\
\hline A0A088A8F0 & Putative H3K9 methyltransferase OS = Apis mellifera GN $=685996$ PE $=4$ SV $=1$ & 6048775.25 & $0.028 \%$ \\
\hline A0A087ZYZ1 & Tubulin beta chain OS $=$ Apis mellifera GN $=\mathrm{LOC} 408782 \mathrm{PE}=3 \mathrm{SV}=1$ & 6014038.938 & $0.028 \%$ \\
\hline AOAOB4J2NO & Uncharacterized protein OS = Apis mellifera GN $=$ LOC550794 PE $=3$ SV $=1$ & 4973486.5 & $0.023 \%$ \\
\hline AOAOB4J2L4 & Uncharacterized protein OS = Apis mellifera GN $=\mathrm{LOC410026} \mathrm{PE}=3 \mathrm{SV}=1$ & 4117948.25 & $0.019 \%$ \\
\hline A0A088AIY2 & Uncharacterized protein $\mathrm{OS}=$ Apis mellifera $\mathrm{GN}=$ mago $\mathrm{PE}=4 \mathrm{SV}=1$ & 4084139.625 & $0.019 \%$ \\
\hline A0A088AFT2 & 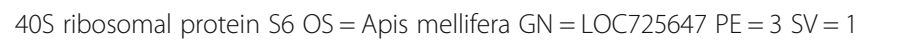 & 3911799.438 & $0.018 \%$ \\
\hline A0A088ATI7 & Uncharacterized protein OS = Apis mellifera GN $=\mathrm{LOC} 409126 \mathrm{PE}=4 \mathrm{SV}=1$ & 3841522.813 & $0.018 \%$ \\
\hline A0A087ZMT8 & Uncharacterized protein OS $=$ Apis mellifera PE $=4 \mathrm{SV}=1$ & 3634688.25 & $0.017 \%$ \\
\hline A0A087ZZN8 & Proteasome subunit alpha type $\mathrm{OS}=$ Apis mellifera $\mathrm{GN}=$ Prosalpha5 $\mathrm{PE}=3 \mathrm{SV}=1$ & 3591316 & $0.017 \%$ \\
\hline A0A087ZV06 & $40 \mathrm{~S}$ ribosomal protein $\mathrm{S} 8 \mathrm{OS}=$ Apis mellifera $\mathrm{GN}=\mathrm{Rps} 8 \mathrm{PE}=3 \mathrm{SV}=1$ & 3381020.75 & $0.016 \%$ \\
\hline A0A088A6T4 & $\begin{array}{l}\text { Succinate dehydrogenase [ubiquinone] flavoprotein subunit, mitochondrial } \\
\mathrm{OS}=\text { Apis mellifera GN=SdhA PE }=3 \mathrm{SV}=1\end{array}$ & 3201888.25 & $0.015 \%$ \\
\hline A0A088ADQ6 & Uncharacterized protein $\mathrm{OS}=$ Apis mellifera $\mathrm{PE}=3 \mathrm{SV}=1$ & 2594249.063 & $0.012 \%$ \\
\hline
\end{tabular}


Table 1 Identification and quantification of proteins in Fraction 2 (Continued)

\begin{tabular}{|c|c|c|c|}
\hline Accession & Description & Abundances & Percentages \\
\hline A0A088A212 & UDP-glucose 6-dehydrogenase OS = Apis mellifera GN $=\mathrm{LOC413356} \mathrm{PE}=3 \mathrm{SV}=1$ & 2218352.25 & $0.010 \%$ \\
\hline A0A088A9V8 & Uncharacterized protein OS = Apis mellifera $\mathrm{PE}=3 \mathrm{SV}=1$ & 2212138 & $0.010 \%$ \\
\hline A0A087EPB0 & Cell division protein FtsZ OS = Lactobacillus kunkeei GN $=\mathrm{ftsZ}$ PE $=3 \mathrm{SV}=1$ & 2057526.938 & $0.010 \%$ \\
\hline AOA088ANZ0 & Uncharacterized protein OS = Apis mellifera GN $=$ LOC551093 PE $=3$ SV $=1$ & 1902225 & $0.009 \%$ \\
\hline A0A088ARA9 & $60 S$ ribosomal protein $\mathrm{L} 13 \mathrm{OS}=$ Apis mellifera $\mathrm{GN}=\mathrm{RpL13} \mathrm{PE}=3 \mathrm{SV}=1$ & 1656290.5 & $0.008 \%$ \\
\hline A0A087EQF2 & $\begin{array}{l}\text { 6-phosphogluconate dehydrogenase, decarboxylating OS = Lactobacillus kunkeei } \\
\mathrm{GN}=J 66 \_01835 \mathrm{PE}=3 \mathrm{SV}=1\end{array}$ & 1644316.875 & $0.008 \%$ \\
\hline A0A088A2L4 & Uncharacterized protein OS = Apis mellifera $\mathrm{PE}=3 \mathrm{SV}=1$ & 1338471.375 & $0.006 \%$ \\
\hline V5 T859 & Glyceraldehyde-3-phosphate dehydrogenase OS=Bifidobacterium sp. Bin2N PE = 3 SV = 1 & 1259643.5 & $0.006 \%$ \\
\hline A0A088AEV2 & Uncharacterized protein OS = Apis mellifera GN $=$ RpL26 PE $=4$ SV $=1$ & 1221172 & $0.006 \%$ \\
\hline A0A087ZW54 & Elongation factor Tu OS = Apis mellifera GN = LOC408328 PE = 3 SV = 1 & 1219225.375 & $0.006 \%$ \\
\hline A0A088AFM4 & Uncharacterized protein OS = Apis mellifera GN $=$ TER94 PE $=3 \mathrm{SV}=1$ & 1214927.25 & $0.006 \%$ \\
\hline D3JZO8 & MRJP5 OS = Apis mellifera PE $=2 \mathrm{SV}=1$ & 802286.1875 & $0.004 \%$ \\
\hline AOA0B4J2P2 & Uncharacterized protein OS = Apis mellifera GN $=$ LOC551386 PE $=3 \mathrm{SV}=1$ & 788959.9375 & $0.004 \%$ \\
\hline A0A088ATP8 & Tubulin alpha chain OS = Apis mellifera PE $=3 \mathrm{SV}=1$ & 654735.875 & $0.003 \%$ \\
\hline A0A087ZUP0 & Uncharacterized protein OS = Apis mellifera $G N=14-3-3 e p s i l o n ~ P E=3 ~ S V=1$ & 638754.125 & $0.003 \%$ \\
\hline A0A088AJ01 & Mitogen-activated protein kinase OS = Apis mellifera GN $=\mathrm{rl} P E=4 \mathrm{SV}=1$ & 616170.75 & $0.003 \%$ \\
\hline A0A087ZMS5 & Uncharacterized protein OS = Apis mellifera $\mathrm{PE}=4 \mathrm{SV}=1$ & 579576 & $0.003 \%$ \\
\hline A0A087EQE2 & S-adenosylmethionine synthase OS $=$ Lactobacillus kunkeei GN = metK PE $=3 \mathrm{SV}=1$ & 554618.25 & $0.003 \%$ \\
\hline A0A088A9W4 & Uncharacterized protein OS = Apis mellifera GN=Flo1 PE $=3 \mathrm{SV}=1$ & 333982.2188 & $0.002 \%$ \\
\hline A0A088ANC5 & $\begin{array}{l}\text { APD-3-like protein; Apidermin 1-like protein; Apidermin 3-like protein OS = Apis } \\
\text { mellifera } \mathrm{GN}=\mathrm{apd}-3 \mathrm{PE}=4 \mathrm{SV}=1\end{array}$ & 332523.6875 & $0.002 \%$ \\
\hline
\end{tabular}

When treated with $0.8 \mu \mathrm{g} / \mathrm{ml}$ of Fraction 2, cell growth continued for $48 \mathrm{~h}$ (Fig. 2b).

\section{Cell migratory effects of protein fractions in an in vitro scratch wound model}

Fraction 2, which showed proliferative effects and was nontoxic in keratinocytes, was investigated further for its migratory effects on $\mathrm{HaCaT}$ cells in an in vitro scratch wound model. Activity on cell migration was measured as the rate of wound coverage over a period of $24 \mathrm{~h}$. As the micrograph in Fig. 3a, at the end of the 24-h treatment, the scratch wound treated with Fraction 2 at the tested concentrations appeared to be much narrower than the vehicle control. The healing rate of keratinocytes treated with $1.6 \mu \mathrm{g} / \mathrm{ml}$ of Fraction 2 (53\%) was dramatically higher than that of the medium-only control at $24 \mathrm{~h}$ (Fig. 3b), implying that Fraction 2 could facilitate keratinocyte migration and may possess potential in wound healing.

\section{Identification and quantification of bioactive protein fractions}

The proteins present in Fraction 2 were successfully identified and quantified using Label-free protein quantification in which absorption peak areas were used for protein quantification and MS/MS fragment ions were used for protein identification. It resulted in identification of a total of 63 proteins including MRJPs, protein kinase and ATP synthase, among which MRJP2 (60\%), MRJP3 (30\%), MRJP7 (2\%), MRJP1 (1\%) were the most abundant and characteristic (Table 1). The total ions chromatograph (TIC) of Fraction 2 and the canonical MS/MS fragmentation sequencing spectrums of the identified MRJPs are shown in Fig. 4.

Bioinformatic analysis of the proteins identified in fraction 2 InterPro protein domain classification revealed that the majority of proteins in Fraction 2 shared the typical domain with major royal jelly proteins (Fig. 5), which was consistent with the mass spectrometric results. According to the COG functional annotation, most proteins were related to translation, ribosomal structure and biogenesis (function class J), posttranslational modification, protein turnover, chaperones (function class $\mathrm{O}$ ), and carbohydrate transport and metabolism (function class G) (Fig. 6 and Table 2), suggesting that these proteins might promote wound healing through the enhancement of protein synthesis. The GO analysis interpreted the roles of proteins in cells, indicating that the most enriched proteins contributed to the translationassociated biological process (Fig. 7). The KEGG pathway analysis illustrated the potential functions and metabolic 


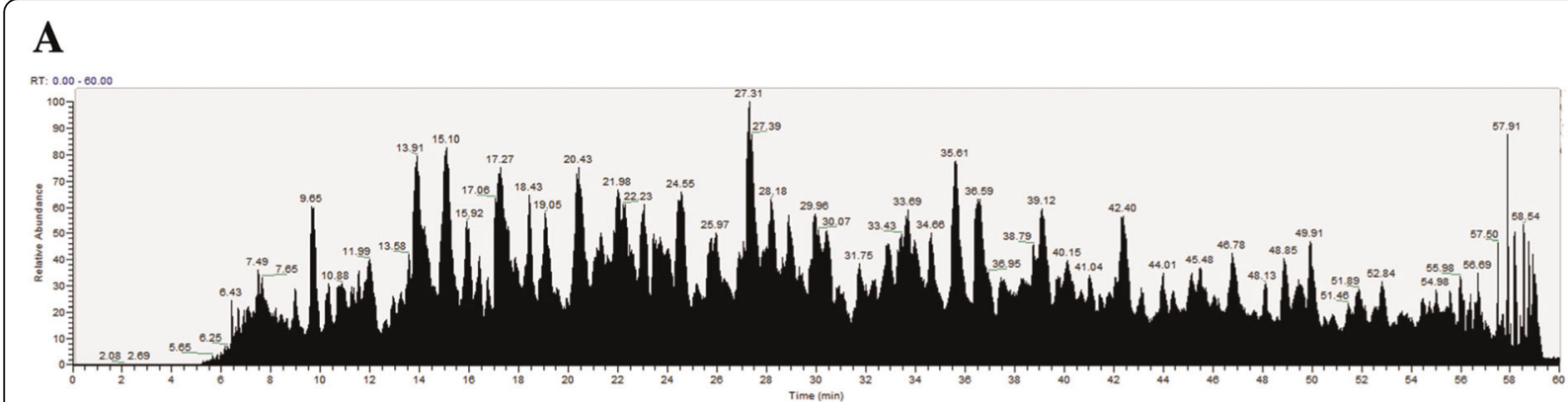

B

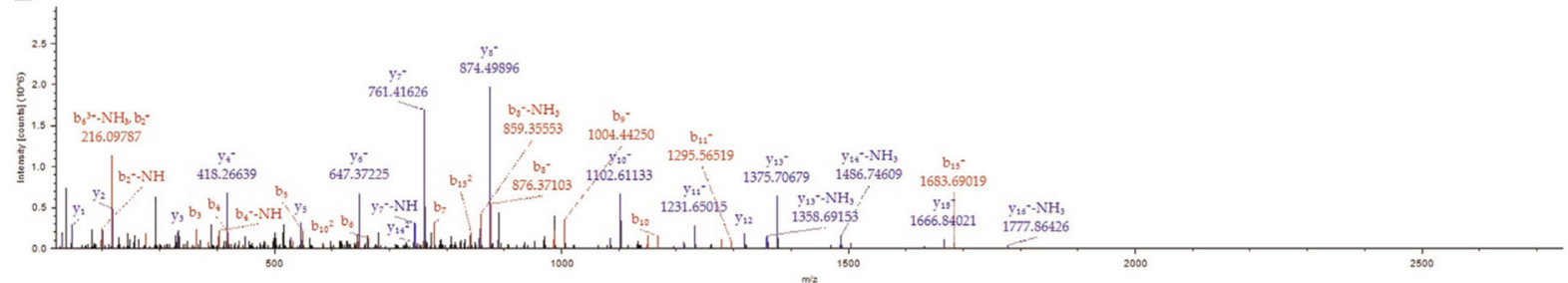

C

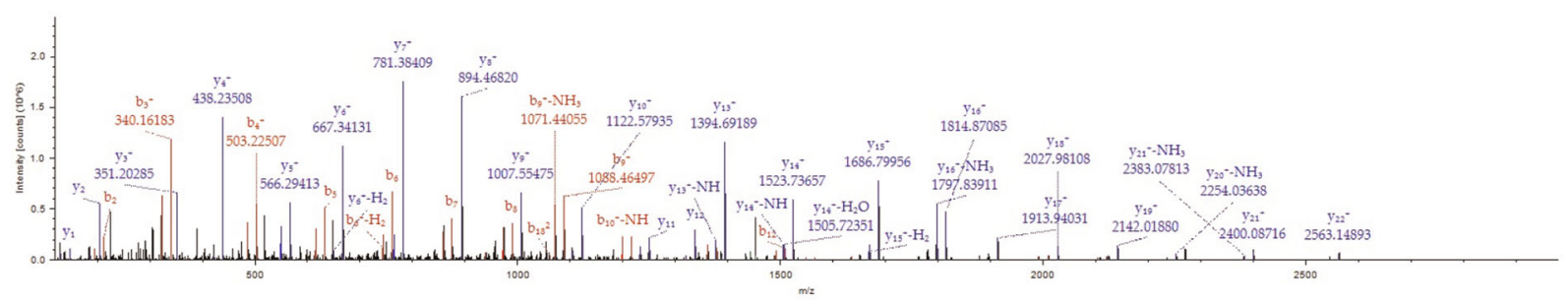

D

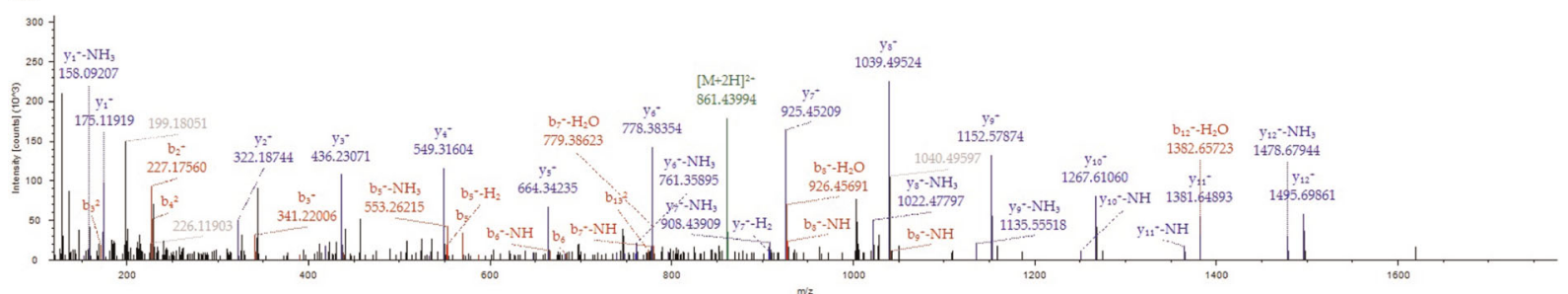

$\mathbf{E}$

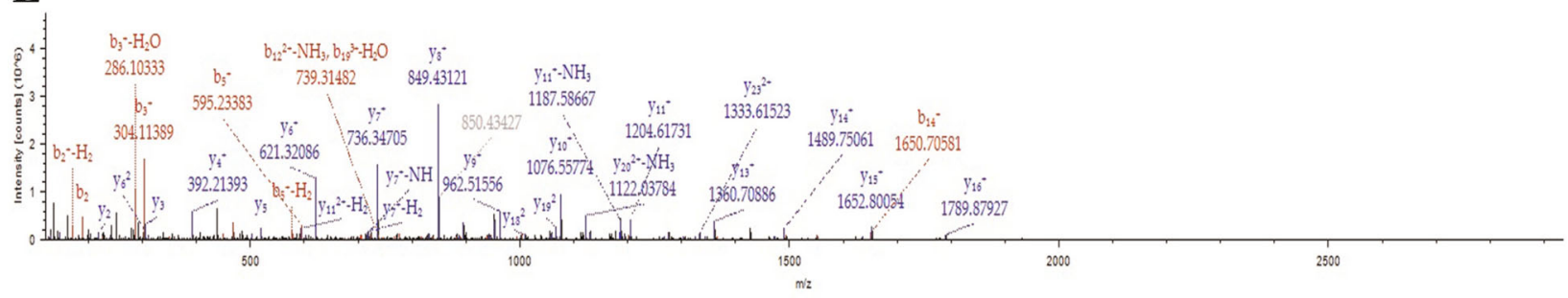

Fig. 4 Identification and quantitative analysis of bioactive protein fraction using Label-free protein quantification method. a Total ions chromatograph of proteins present in Fraction 2. b Partial MS/MS fragmentation sequencing spectrum of MRJP2 (SQFGENNVQYQGSEDILNTQSLAK). c Partial MS/MS fragmentation sequencing spectrum of MRJP3 (NPQYEENNVQYEGSQDILNTQSFGK). d Partial MS/MS fragmentation sequencing spectrum of MRJP7 (ILNNDLNFNDINFR). e Partial MS/MS fragmentation sequencing spectrum of MRJP1 (TSDYQQNDIHYEGVQNILDTQSSAK)

procedures of proteins in biological system. In accordance with COG and GO analysis, many proteins were concerned with transport and catabolism (cellular processes), and translation (genetic information processing) (Fig. 8). It is noteworthy that masses of proteins (21 proteins) were in connection with human diseases such as Non-alcoholic fatty liver disease, Alzheimer's disease, Parkinson's disease and HTLV-I infection. 


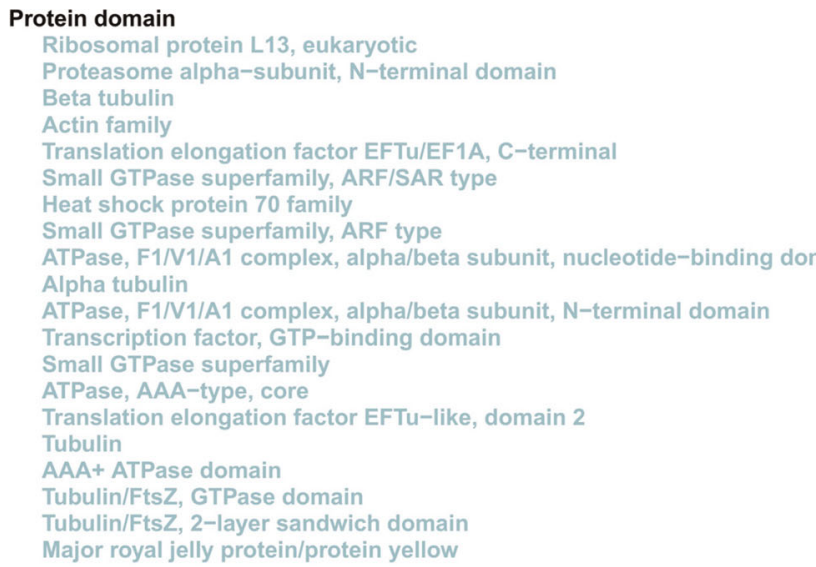

Fig. 5 InterPro protein domain classification of proteins identified in Fraction 2

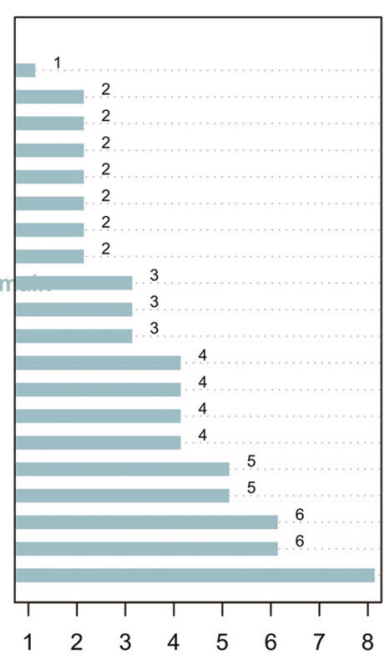

Number of Protein

\section{Discussion}

Cutaneous wound healing impairment has always been a serious health problem as it may result in ulcers, relapse, amputation and even death. Over the past decades, with the high incidence of diabetes, an increasing number of patients are suffering from one of the most typical complications-foot ulcers. Only about half of all such ulcers can be cured and there is a high risk of relapse. It has been reported that one amputation occurs every $30 \mathrm{~s}$ and as many as 2,500 patients undergo some form of

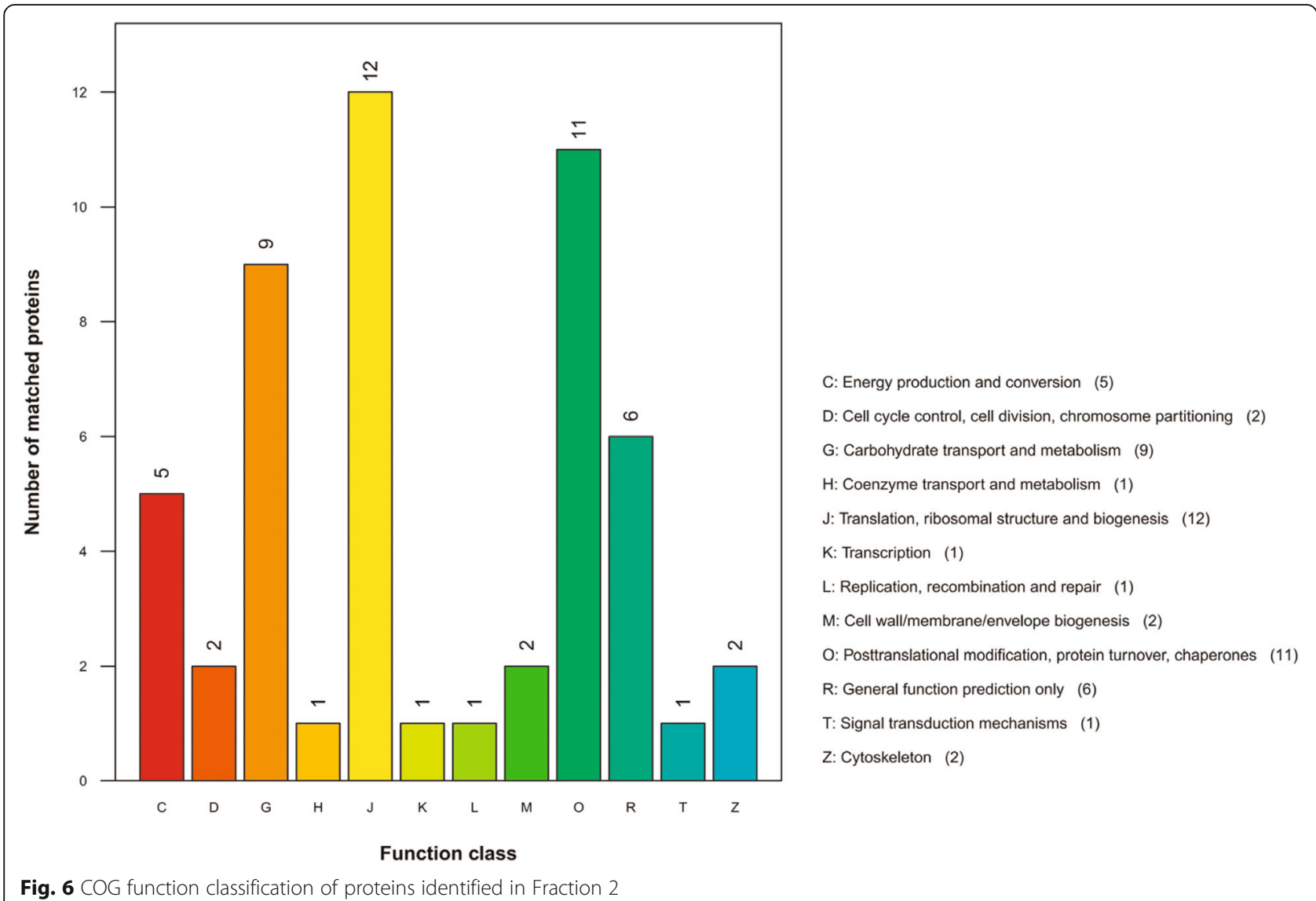




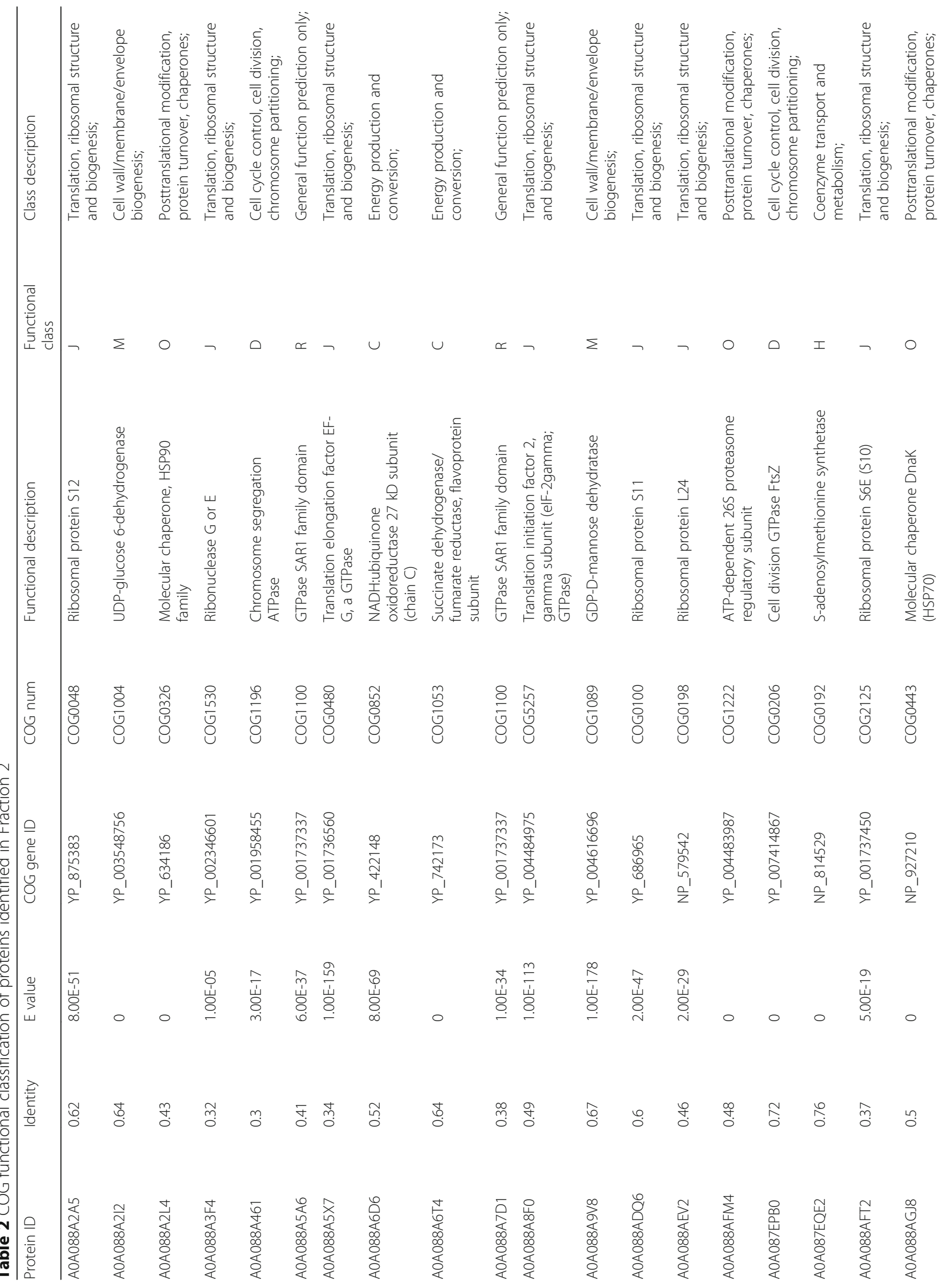




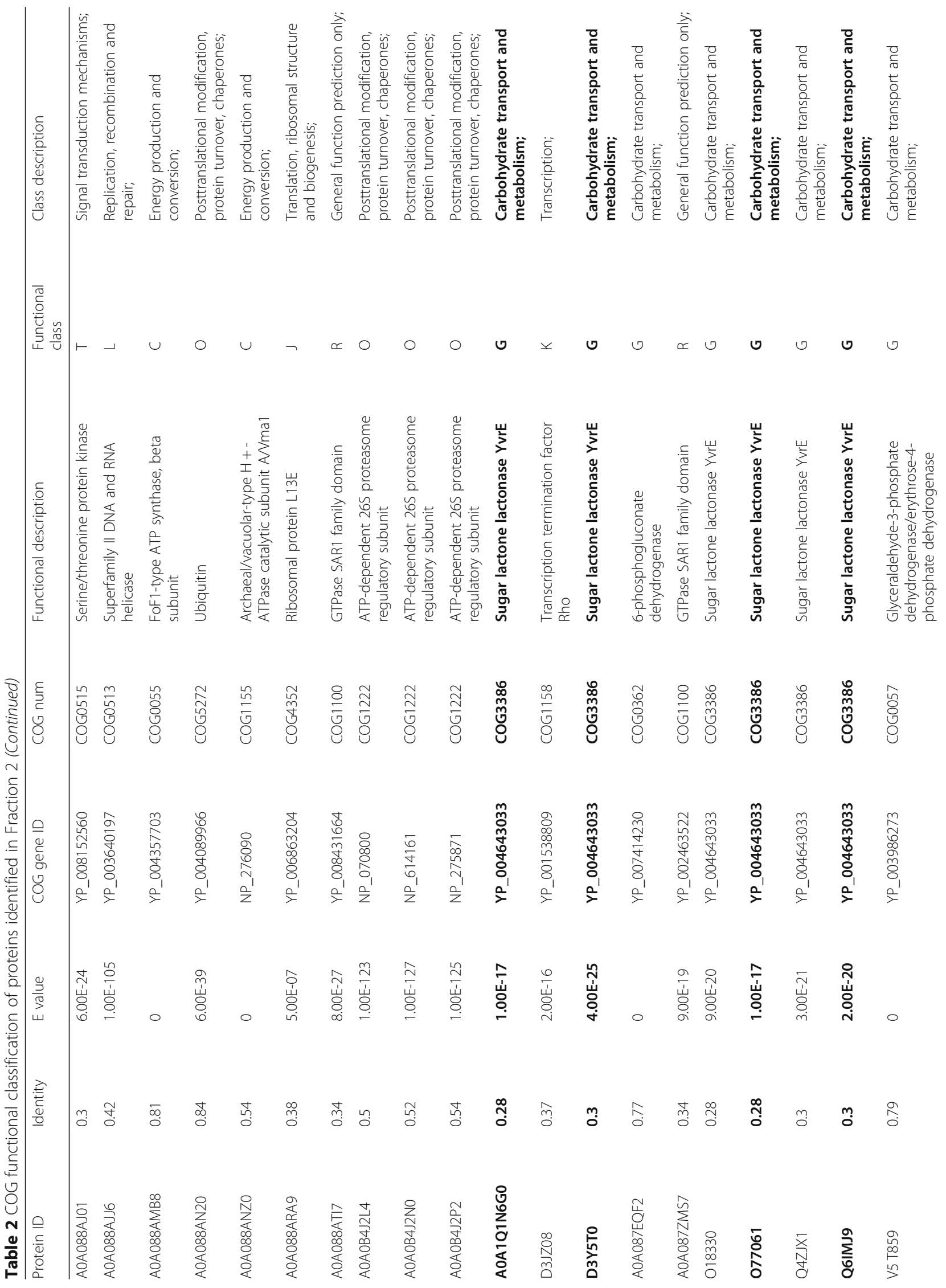




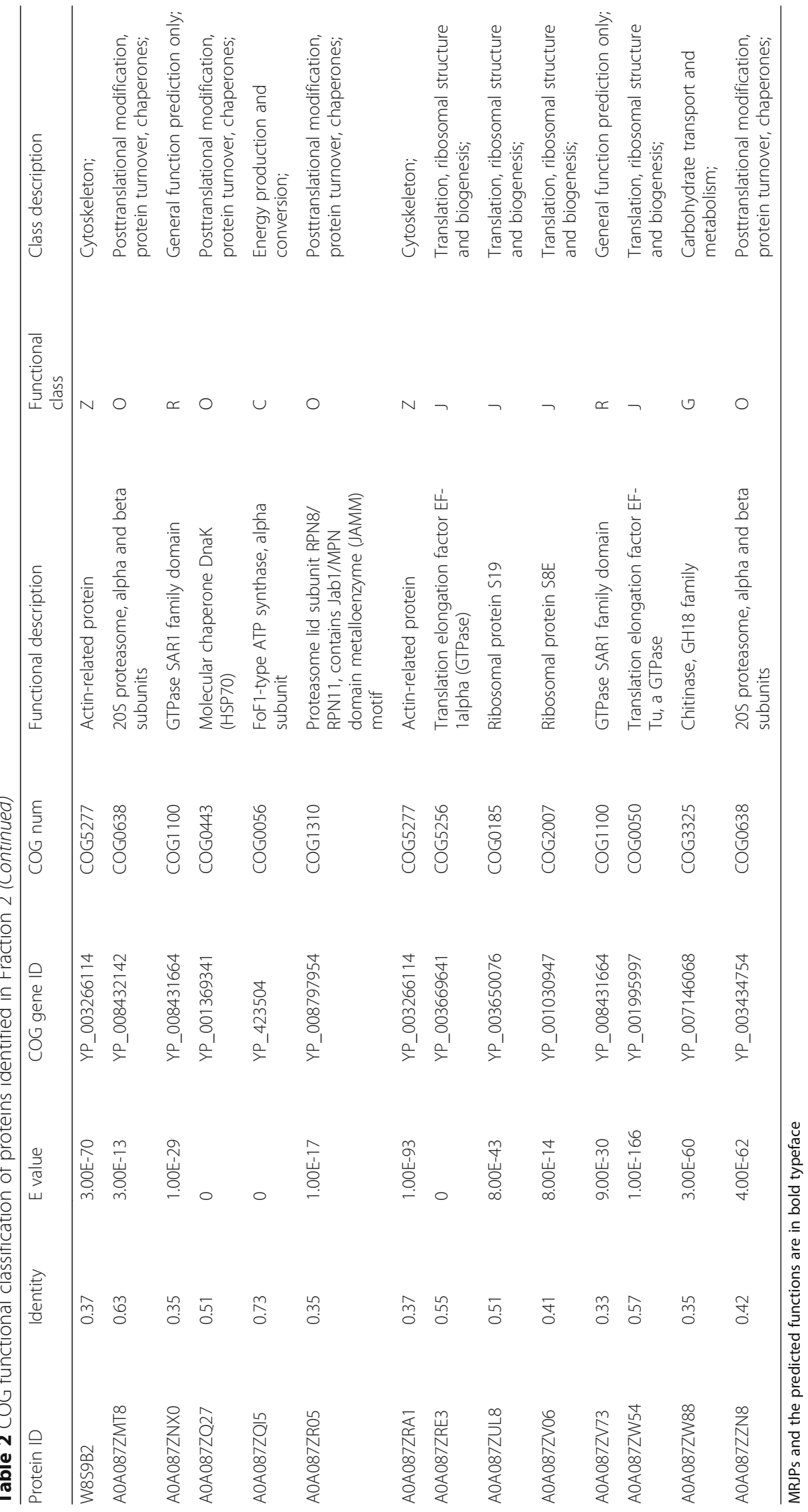




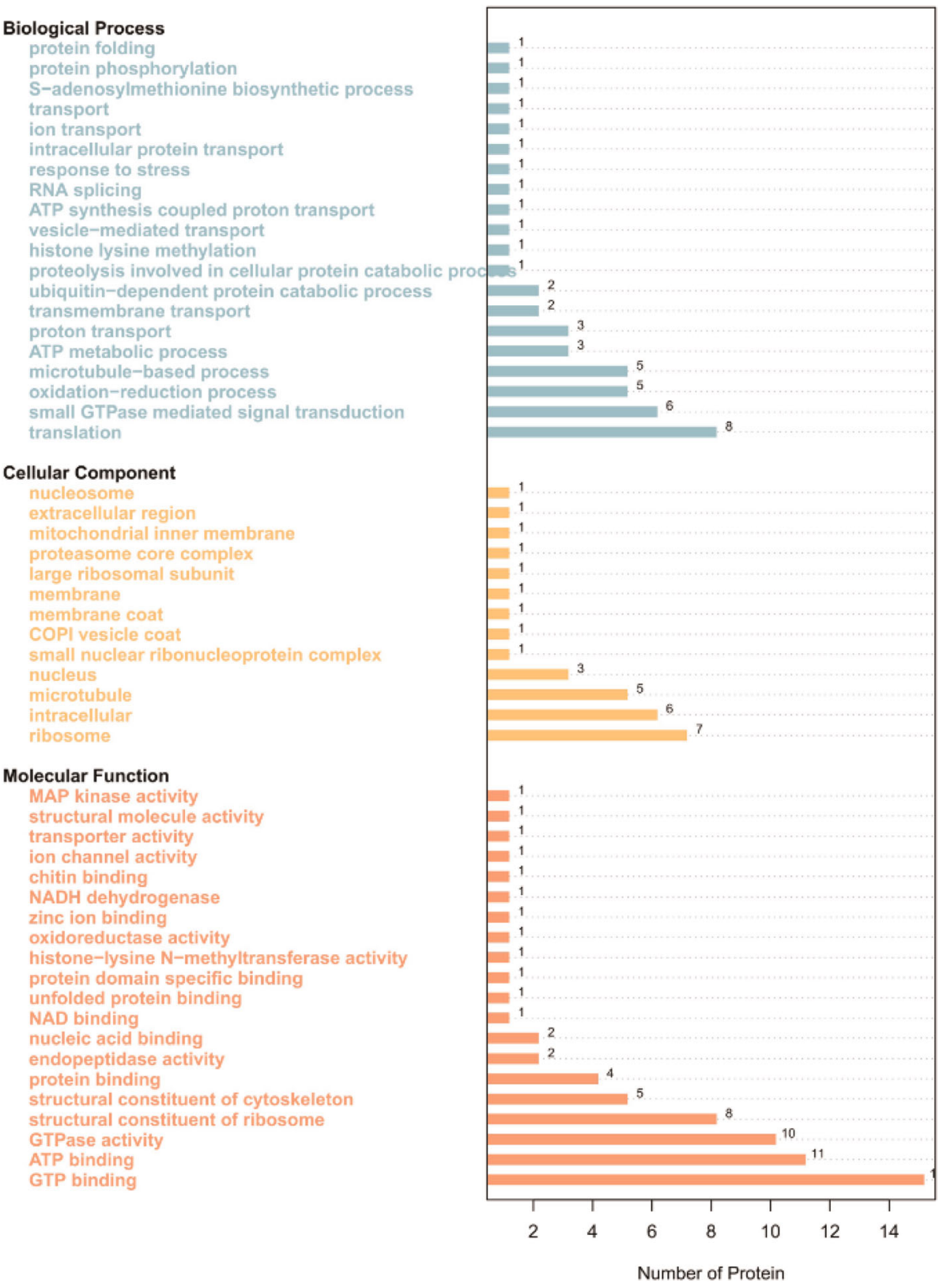

Fig. $7 \mathrm{GO}$ functional annotation of proteins identified in Fraction 2

amputation every single day [31]. According to the International Diabetes Federation (IDF), the diabetic population worldwide is predicted to increase to 592 million in 2035. At present, suturing and skin-grafting are the primary therapies used to treat deep or large defective wounds, and antibiotic therapies are usually applied to infected wounds. There is still no effective agent that promotes the healing of either intractable wounds or diabetic foot ulcers. The discovery and development of novel wound repairing drugs and treatments is thus of significant importance.
Wound healing is a complicated dynamic process which generally involves three consecutive and interrelated phases - inflammatory reactions, proliferative stage and tissue remodelling [32]. An inflammatory reaction occurs in the early stages of wound formation, in which inflammatory cells phagocytose bacteria and cell debris from necrotic tissue, serving as a form of wound cleaning. Subsequently, fibroblasts proliferate to promote the synthesis of extracellular matrix, while granulation tissue grows at the bottom and edges of the wound, filling up the incisions that will be covered by 


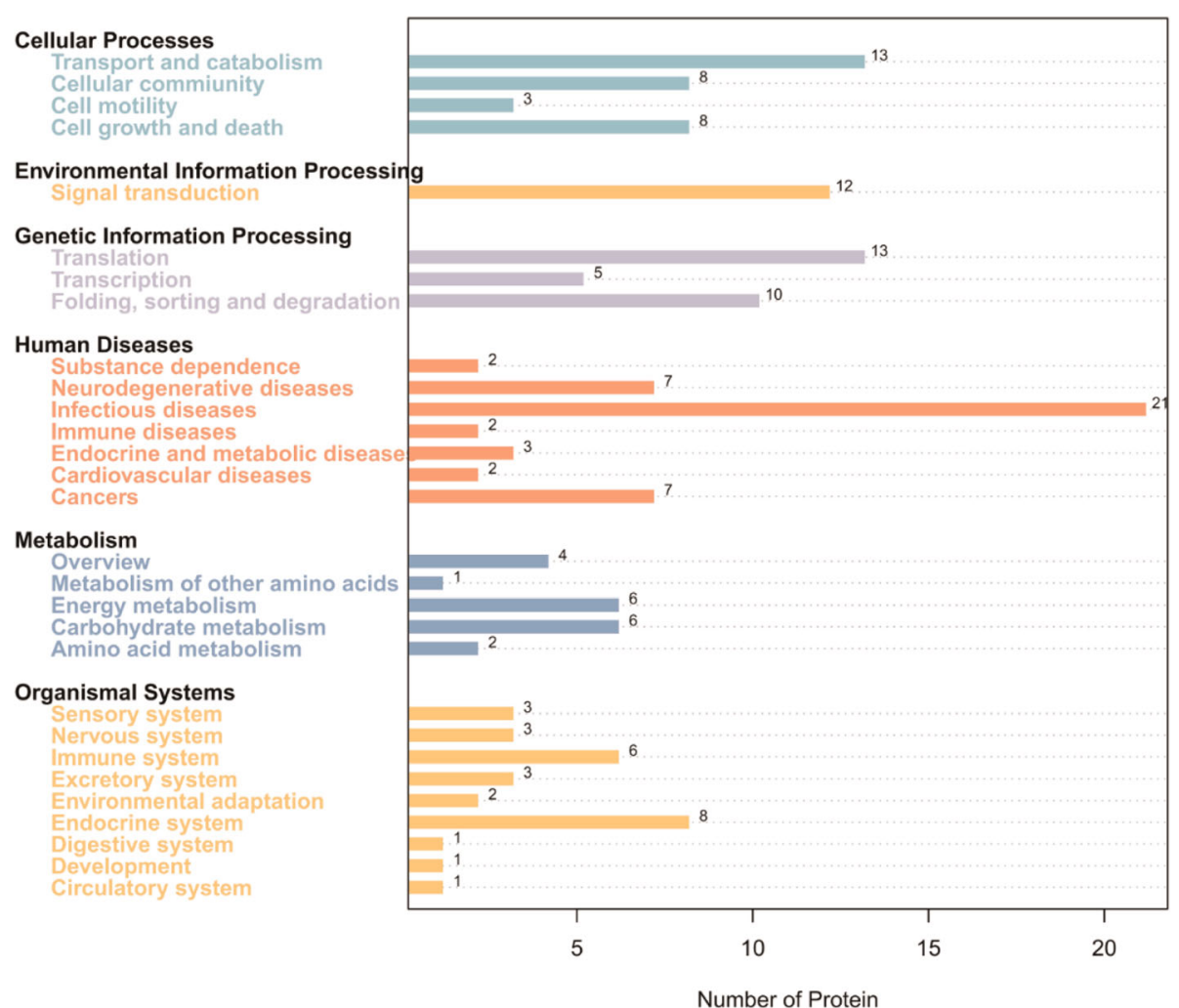

Fig. 8 KEGG pathway analysis of proteins identified in Fraction 2

proliferative and migrating basal cells to form an epithelial monolayer. Keratinocytes then proliferate and move towards the centre of the wound, thereby covering the wound surface and completing wound healing. The proliferation, migration and differentiation of fibroblasts and keratinocytes thus plays a vital role in wound reepithelialization and reparation [33-36].

In this study, we attempted to evaluate the efficacy of royal jelly proteins on human epidermal keratinocytes to identify bioactive components of royal jelly with woundhealing activity and their mechanisms. Following fractionation of royal jelly water-soluble proteins, SDSPAGE analysis showed that Fraction 1 was a relatively pure protein with a mass of $55 \mathrm{kDa}$, most likely MRJP1, and Fraction 2 was a mixture of proteins with molecular weights ranging from 50 to $60 \mathrm{kDa}$ (Fig. 1). Fraction 1 was ineffective in wound healing and was even toxic to the growth of $\mathrm{HaCaT}$ cells, while Fraction 2 induced some cell growth (Fig. 2). Compared with being incubated with BSA, cells incubated with Fraction 2 showed a significant increase in cell growth (Fig. 2b), suggesting that the proliferative effects of Fraction 2 were different from the nutritive effects of BSA. In addition, as pure MRJP1 and Fraction 1 had very similar profiles and biological effects on the cell viability of $\mathrm{HaCaT}$ (data not shown), Fraction 1 was further confirmed as MRJP1. It was surprising that MRJP1, the most abundant MRJP [37], reported to possess various bioactivities [14, 38, 39] including weak up-regulation of mRNA expression of cytokines (TNF- $\alpha$, IL- $1 \beta$ and TGF- $\beta$ ) in cultured human primary keratinocytes [40], was found to be devoid of having an effect on $\mathrm{HaCaT}$ cell growth. Owing to the toxicity and inefficacy of MRJP1, we only investigated Fraction 2 further for its cell migratory effects on an in vitro scratch wounding model. The proportion of wound healing induced by Fraction $2(1.6 \mu \mathrm{g} / \mathrm{ml})$ was significantly higher after $24 \mathrm{~h}$ incubation than that of the vehicle control (Fig. 3b). As shown in Fig. 2b, however, $1.6 \mu \mathrm{g} / \mathrm{ml}$ of Fraction 2 had little effect on the growth of $\mathrm{HaCaT}$ cells at $24 \mathrm{~h}$; moreover, fraction samples used in the wound scratching assay were reconstituted in serum-free medium which had no effect on cell growth. Therefore, effects of Fraction 2 on cell growth and medium-induced cell proliferation in the wound closure observed can be ignored. Fraction 2 may thus mediate wound healing via keratinocyte migration.

Interestingly, Fraction 2 did not function in a strict dose-dependent manner concerning its proliferative and migration efficacy towards keratinocytes, efficacy declining at higher concentrations (Figs. $2 \mathrm{~b}$ and 3). This phenomenon might be caused by the antagonistic effect of the complicated compositions within Fraction 2, and 
thus further purification of the fraction or expression of each component as a pure recombinant protein would be desirable to facilitate further functional investigation. In addition, as the procedure of wound healing is complex, involving various categories of cells, cytokines, growth factors, and many other intracellular/extracellular components [41], it will be important to explore the regulatory effects of these proteins on other types of cells such as macrophages.

Qualitative and quantitative analysis of Fraction 2 revealed that the main biologically-active components were MRJP2, MRJP3 and MRJP7. COG analysis demonstrated that MRJP2, MRJP3 and MRJP7 were associated with carbohydrate transport and metabolism (Fig. 6 and Table 2), which might be beneficial to the conversion into nutrition such as proteins to promote wound healing. However, the precise mechanisms underlying the wound healing activity need to be further investigated to facilitate better understanding of the wound repair functions of royal jelly in the future. This is the first experimental evidence that MRJP2, MRJP3 and/or MRJP7 may possess potential wound healing function, providing valuable lead compounds to be developed into novel wound repairing medications.

\section{Conclusions}

In this study, the potential wound healing activity of royal jelly proteins was first time to be concerned. As a result, MRJP2, MRJP3 and MRJP7 present in a watersoluble protein fraction were speculated to possess potential wound repairing activity. Our finding that MRJPs may modulate wound healing by stimulating keratinocyte growth and migration suggests that these naturally-occurring proteins would be biomaterials with potential for development as novel wound-healing agents.

\section{Abbreviations}

10-HDA: 10-hydroxy-2-decenoic acid; ACN: Acetonitrile; BSA: Bovine serum albumin; COG: Cluster of Orthologous Groups; DMEM: Dulbecco's Modified Eagle's Medium; FBS: Foetal bovine serum; GO: Gene ontology; HaCaT: Human epidermal keratinocytes; KEGG: Kyoto Encyclopedia of Genes and Genomes; MRJPs: Major royal jelly proteins; MTT: 3-(4, 5-Dimethylthiazol-2-yl)-2,5-diphenyltetrazolium bromide; TGF: Transforming growth factor; TIC: Total ions chromatograph
}

\section{Acknowledgements}

Not applicable.

\section{Authors' contributions}

$\mathrm{SS}$ and $\mathrm{YL}$ conceived and designed the experiments; $\mathrm{YL}, \mathrm{QS}, \mathrm{MZ}$ and $\mathrm{CL}$ performed the experiments; YL, QS, MZ, CL and SS analysed the data; YL, QS, JF and SS wrote the paper. All authors read and approved the final manuscript.

\section{Funding}

This work was supported by grants from the Natural Science Foundation of Fujian Province (No. 2019J01408), the National Natural Science Foundation of China (No. 31500753), and the Earmarked Fund for Modern Agro-industry Technology Research System (No.CARS-44-KXJ4). The funding body provided financial support and had no role in the design of the study, collection, analysis, interpretation of data, or writing the manuscript.

\section{Availability of data and materials}

The datasets used and/or analysed during the current study available from the corresponding author on reasonable request.

Ethics approval and consent to participate

Not applicable.

Consent for publication

Not applicable.

\section{Competing interests}

The authors declare that they have no competing interests.

\section{Author details}

${ }^{1}$ College of Bee Science, Fujian Agriculture and Forestry University, Fuzhou 350002, China. ${ }^{2}$ Key Laboratory of RNA Biology, Institute of Biophysics, Chinese Academy of Sciences, Beijing 100101, China.

Received: 21 March 2019 Accepted: 4 July 2019

Published online: 12 July 2019

References

1. Melliou E, Chinou I. Chemistry and bioactivity of royal jelly from Greece. J Agric Food Chem. 2005;53(23):8987-92

2. Sabatini AG. Quality and standardisation of royal jelly. J ApiProduct ApiMedical Sci. 2009;1(1):16-21.

3. Zhang L, Fang Y, Li R, Feng M, Han B, Zhou T, Li J. Towards posttranslational modification proteome of royal jelly. J Proteome. 2012;75(17):5327-41.

4. Ramadan MF, Al-Ghamdi A. Bioactive compounds and health-promoting properties of royal jelly: a review. J Funct Foods. 2012:4(1):39-52.

5. Honeybee Genome Sequencing Consortium. Insights into social insects from the genome of the honeybee Apis mellifera. Nature. 2006:443(7114): 931-49.

6. Bărnuțiu LI, Marghitas LA, Dezmirean DS, Mihai CM, Bobis O. Chemical composition and antimicrobial activity of royal jelly - review. Sci Pap. 2011; 44(2):67-72.

7. Bílikova K, Huang SC, Lin IP, Šimuth J, Peng CC. Structure and antimicrobial activity relationship of royalisin, an antimicrobial peptide from royal jelly of Apis mellifera. Peptides. 2015;68:190-6.

8. Fratini F, Cilia G, Mancini S, Felicioli A. Royal Jelly: an ancient remedy with remarkable antibacterial properties. Microbiol Res. 2016;192:130-41.

9. Tseng JM, Huang JR, Huang HC, Tzen JTC, Chou WM, Peng CC. Facilitative production of an antimicrobial peptide royalisin and its antibody via an artificial oil-body system. Biotechnol Prog. 2011;27(1):153-61.

10. Karaca T, Şimșek N, Uslu S, Kalkan Y, Can I, Kara A, Yörük M. The effect of royal jelly on CD3(+), CD5(+), CD45(+) T-cell and CD68(+) cell distribution in the colon of rats with acetic acid-induced colitis. Allergol Immunopathol Madr. 2012:40(6):357-61.

11. Kimura Y. Antitumor and antimetastatic actions of various natural products. Stud Nat Prod Chem. 2008;34(C):35-76.

12. El-Nekeety AA, El-Kholy W, Abbas NF, Ebaid A, Amra HA, Abdel-Wahhab MA Efficacy of royal jelly against the oxidative stress of fumonisin in rats. Toxicon Off J Int Soc Toxinology. 2007;50(2):256-69.

13. Mihajlovic D, Vucevic D, Chinou I, Colic M. Royal jelly fatty acids modulate proliferation and cytokine production by human peripheral blood mononuclear cells. Eur Food Res Technol. 2014:238(5):881-7.

14. Kamakura M, Suenobu N, Fukushima M. Fifty-seven-kDa protein in royal jelly enhances proliferation of primary cultured rat hepatocytes and increases albumin production in the absence of serum. Biochem Biophys Res Commun. 2001;282(4):865-74.

15. Bucekova M, Sojka M, Valachova I, et al. Bee-derived antibacterial peptide, defensin-1, promotes wound re-epithelialisation in vitro and in vivo. Sci Rep. 2017;7(1):7340.

16. Abdelatif M, Yakoot M, Etmaan M. Safety and efficacy of a new honey ointment on diabetic foot ulcers: a prospective pilot study. J Wound Care. 2008;17(3):108-10 
17. El-Gayar MH, Aboshanab KM, Aboulwafa MM, Hassouna NA. Antivirulence and wound healing effects of royal jelly and garlic extract for the control of MRSA skin infections. Wound Med. 2016;13:18-27.

18. Temamogullari FK, Hayat A, Baba F. Comparison of the royal jelly and povidone iodine on wound healing in rabbits. J Anim Vet Adv. 2007;6(2):203-5.

19. Yang $X Y$, Yang D, Zhang W, Wang JM, Li CY, Ye H, Lei KF, Chen XF, Shen $\mathrm{NH}$, Jin LQ, Wang JG. 10-Hydroxy-2-decenoic acid from royal jelly: a potential medicine for RA. J Ethnopharmacol. 2010;128(2):314-21.

20. Kim J, Kim Y, Yun H, Park H, Kim SY, Lee KG, Han SM, Cho Y. Royal jelly enhances migration of human dermal fibroblasts and alters the levels of cholesterol and sphinganine in an in vitro wound healing model. Nutr Res Pract. 2010;4(5):362-8.

21. Park HM, Hwang E, Lee KG, Han S-M, Cho Y, Kim SY. Royal jelly protects against ultraviolet B-induced photoaging in human skin fibroblasts via enhancing collagen production. J Med Food. 2011;14(9):899-906.

22. Tsuruma Y, Maruyama H, Araki Y. Effect of a glycoprotein (apisin) in royal jelly on proliferation and differentiation in skin fibroblast and osteoblastic cells. Nippon Shokuhin Kagaku Kogaku Kaishi. 2011;58(3):121-6.

23. Chen D, Xin XX, Qian HC, Yu ZY, Shen LR. Evaluation of the major royal jelly proteins as an alternative to fetal bovine serum in culturing human cell lines. J Zhejiang Univ Sci B. 2016:17(6):476-83.

24. Smith PK, Krohn RI, Hermanson GT, Mallia AK, Gartner FH, Provenzano MD, Fujimoto EK, Goeke NM, Olson BJ, Klenk DC. Measurement of protein using bicinchoninic acid. Anal Biochem. 1985;150(1):76-85.

25. Banerjee J, Das Ghatak P, Roy S, Khanna S, Sequin EK, Bellman K, Dickinson $B C$, Suri P, Subramaniam W, Chang CJ, Sen CK. Improvement of human keratinocyte migration by a redox active bioelectric dressing. PLoS One. 2014;9(3):e89239.

26. Mitchell AL, Attwood TK, Babbitt PC, Blum M, Bork P, Bridge A, Brown SD, Chang HY, El-Gebali S, Fraser MI. InterPro in 2019: improving coverage, classification and access to protein sequence annotations. Nucleic Acids Res. 2019:47(D1):D351-60.

27. Tatusov RL, Fedorova ND, Jackson JD, Jacobs AR, Kiryutin B, Koonin EV, Krylov DM, Mazumder R, Mekhedov SL, Nikolskaya AN. The COG database: an updated version includes eukaryotes. BMC Bioinformatics. 2003;4:41.

28. Ashburner M, Ball CA, Blake JA, Botstein D, Butler H, Cherry JM, Davis AP, Dolinski K, Dwight SS, Eppig JT. Gene ontology: tool for the unification of biology. Nat Genet. 2000;25(1):25-9.

29. Kanehisa M, Goto S, Sato Y, Furumichi M, Tanabe M. KEGG for integration and interpretation of large-scale molecular data sets. Nucleic Acids Res. 2012;40:D109-14.

30. Altschul SF, Madden TL, Schäffer AA, Zhang J, Zhang Z, Miller W, Lipman DJ. Gapped BLAST and PSI-BLAST: a new generation of protein database search programs. Nucleic Acids Res. 1997;25(17):3389-402.

31. Henshaw FR, Twigg SM, McLennan SV. What's the buzz: bee products and their potential value in diabetic wound healing. J Diabet Foot Complicat. 2014:6(2):24-39.

32. Martin $P$. Wound healing-aiming for perfect skin regeneration. Science. 1997:276(5309):75-81.

33. Block ER, Tolino MA, Lozano JS, Lathrop KL, Sullenberger RS, Mazie AR, Klarlund JK. Free edges in epithelial cell sheets stimulate epidermal growth factor receptor signaling. Mol Biol Cell. 2010;21(13):2172-81.

34. Plikus MV, Gay DL, Treffeisen E, Wang A, Supapannachart RJ, Cotsarelis G. Epithelial stem cells and implications for wound repair. Semin Cell Dev Biol. 2012;23(9):946-53.

35. Sivamani RK, Garcia MS, Isseroff RR. Wound re-epithelialization: modulating keratinocyte migration in wound healing. Front Biosci J Virtual Libr. 2007; 12(1):2849-68

36. Woodley DT, Chen JD, Kim JP, Sarret Y, Iwasaki T, Kim YH, O'Keefe EJ. Reepithelialization. Human keratinocyte locomotion. Dermatol Clin. 1993;11(4): 641-6.

37. Shen L, Zhang W, Jin F, Zhang L, Chen Z, Liu L, Parnell LD, Lai CQ, Li D. Expression of recombinant AccMRJP1 protein from royal jelly of Chinese honeybee in Pichia pastoris and its proliferation activity in an insect cell line. J Agric Food Chem. 2010;58(16):9190-7.

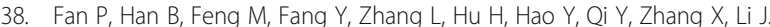
Functional and proteomic investigations reveal major royal jelly protein 1 associated with anti-hypertension activity in mouse vascular smooth muscle cells. Sci Rep. 2016;6:30230.

39. Kamakura M. Royalactin induces queen differentiation in honeybees. Nature 2011;473(7348):478-83.
40. Majtan J, Kumar P, Majtan T, Walls AF, Klaudiny J. Effect of honey and its major royal jelly protein 1 on cytokine and MMP-9 mRNA transcripts in human keratinocytes: Activation of keratinocytes by honey and its MRJP1. Exp Dermatol. 2010;19(8):e73-9.

41. Breitkreutz D, Mirancea N, Nischt R. Basement membranes in skin: unique matrix structures with diverse functions? Histochem Cell Biol. 2009;132(1):1-10.

\section{Publisher's Note}

Springer Nature remains neutral with regard to jurisdictional claims in published maps and institutional affiliations.
Ready to submit your research? Choose BMC and benefit from:

- fast, convenient online submission

- thorough peer review by experienced researchers in your field

- rapid publication on acceptance

- support for research data, including large and complex data types

- gold Open Access which fosters wider collaboration and increased citations

- maximum visibility for your research: over $100 \mathrm{M}$ website views per year

At $\mathrm{BMC}$, research is always in progress.

Learn more biomedcentral.com/submissions 